\title{
Lipomatous Tumors in Pediatric Patients: A Retrospective Analysis of 50 cases
}

\author{
Mine ÖZŞEN ${ }^{\mathbb{D}}$, Ulviye YALÇINKAYA² ${ }^{\mathbb{D}}$, Zeynep YAZICI ${ }^{\mathbb{D}}$, Mehmet Bartu SARISÖZEN ${ }^{4}$ \\ 'Department of Pathology, Erzurum Regional Training and Research Hospital, ERZURUM, TURKEY \\ Department of ${ }^{2}$ Pathology, ${ }^{3}$ Radiology, ${ }^{4}$ Orthopedics and Traumatology, Uludag University Faculty of Medicine, BURSA, TURKEY
}

\begin{abstract}
Objective: Although lipomatous tumors are the most common type of mesenchymal tumors in adults, they account for less than $10 \%$ of all soft tissue lesions in pediatric patients. In this descriptive study, we aim to present our series of pediatric lipomatous tumors consisting of lipoma, neural fibrolipoma, lipoblastoma, atypical lipomatous tumor, myxoid liposarcoma and pleomorphic liposarcoma, and to evaluate the clinicopathological characteristics of these tumors in reference to the literature.
\end{abstract}

Material and Method: In this study, pediatric lipomatous tumor cases diagnosed between 2002 and 2018 were screened from pathological archives and retrospectively evaluated.

Results: A total of 50 cases were diagnosed with lipomatous tumor within the mentioned period. Of the total cases, 24 were female (48\%) and 26 were male (52\%), with age distribution ranging from 1 to 204 months. Histopathological examination revealed lipoma in 26 cases (52\%), lipoblastoma in 19 (38\%), atypical lipomatous tumor in 2 (4\%), myxoid liposarcoma in 2 (4\%), and pleomorphic liposarcoma in 1 case (2\%).

Conclusion: Although lipomatous tumors are the most common type of mesenchymal tumors; they rarely occur in children. Since there is a limited number of studies on pediatric lipomatous tumors in the literature, there is insufficient data on the prevalence and incidence of these tumors. These tumors may slowly enlarge to greater sizes, especially those localized in deep tissues, and may cause various clinical symptoms by compressing surrounding tissues. Local recurrences may occur, even after total excision, and require close monitoring.

Key Words: Childhood, Lipoma, Lipoblastoma, Liposarcoma

\section{INTRODUCTION}

Lipomatous tumors including lipoma, lipoblastoma, hibernoma, atypical lipomatous tumor and liposarcoma play an important role in soft tissue pathology, as they are common in adults. Lipoma, the most common soft tissue tumor, accounts for $16 \%$ of all adult soft tissue tumors. Although lipomatosis can be detected from 2 years of age, patients are usually diagnosed in adulthood. The average diagnosis age for hibernoma is 38 years, and only $5 \%$ of patients are diagnosed under the age of 18 . Unlike other types of benign lipomatous tumors, $90 \%$ of patients with lipoblastoma are diagnosed under 3 years of age, and very few are adolescents or adults. Atypical malignant lipomatous tumors, which account for $40-45 \%$ of all liposarcomas, are rarely seen in children. Myxoid liposarcoma, accounting for $15-20 \%$ of liposarcomas and $5 \%$ of soft-tissue sarcomas, typically occurs in adulthood, and is the most common type of liposarcoma in children and adolescents (1-6). Lipomatous tumors account for less than $10 \%$ of soft-tissue lesions within the first two decades of life (7).

In this descriptive study, we aim to present our series of pediatric lipomatous tumors including lipoma, neural fibrolipoma, lipoblastoma, atypical lipomatous tumor, myxoid liposarcoma and pleomorphic liposarcoma, and evaluate the clinicopathological characteristics of these tumors in reference to the literature.

\section{MATERIAL and METHODS}

In this study, we screened the archives of Faculty of Medicine, Department of Medical Pathology for the pediatric lipomatous tumor cases diagnosed between 2002 and 2018. The hematoxylin and eosin-stained slides were reexamined, and histopathological features were documented. The cases were evaluated retrospectively according to age, gender, localization, and clinicopathological features. The study was approved by the local Clinical Research Ethics Committee, dated 17 September 2018 and numbered 2018$15 / 3$. 


\section{RESULTS}

A total of 50 cases were diagnosed with lipomatous tumors within the mentioned period (Table I). There were 24 females (48\%) and 26 males (52\%), with an age distribution ranging from 1 to 204 months (mean value of $73 \pm 63.3$ months). The histopathological examination revealed lipoma in 26 cases (52\%), lipoblastoma in 19 (38\%), atypical lipomatous tumor in $2(4 \%)$, myxoid liposarcoma in $2(4 \%)$, and pleomorphic liposarcoma in 1 case (2\%).

Of the 26 cases diagnosed with lipoma, 15 were male (57.7\%) and 11 were female $(42.3 \%)$. The mean age of the cases was 97.3 \pm 56.2 months (range:4-204 months). The mean tumor diameter was $4.84 \pm 3.1 \mathrm{~cm}$ (range:1.1-12.5 cm).

Locations of lipomatous tumors were as follows: 8 (30.7\%) were in the head and neck region (one conjunctiva, one oral cavity, one tongue, one ears, one head and three neck), 4 (15.3\%) lumbar , 2 (7.7\%) lumbosacral, 2 (7.7\%) spinal site, 2 (7.7\%) back region, 2 (7.7\%) arms, 1 (3.9\%) chest, 1 (3.9\%) gluteus, 1 (3.9\%) heel, 1 (3.9\%) labium major, $1(3.9 \%)$ axilla, and 1 (3.9\%) fingers. Tumor types were fibrolipoma in three cases (11.5\%), spindle cell lipoma in one case (3.9\%), and intramuscular lipoma in two cases $(7.7 \%)$
While 24 of the cases presented to the clinic with complaints of swelling, 2 were detected incidentally.

The 11 cases with available radiological imaging findings showed a well-circumscribed mass lesion with soft tissue echogenicity.

Of the 19 lipoblastoma cases, 11 were male (57.9\%) and 8 were female $(42.1 \%)$. The mean age of these cases was $20.3 \pm 29.4$ months (range: 1-108 months). The mean tumor diameter was $4.87 \pm 2.4 \mathrm{~cm}$ (range: $0.3-9 \mathrm{~cm}$ ) with the exception of 2 cases with unavailable tumor diameter measurements as these cases were referred from other institutions for consultation.

The locations of lipoblastoma were as follows: the thigh in 4 cases $(21.1 \%)$, gluteal area in $2(10.6 \%)$, inguinal region in $2(10.6 \%)$, feet in $2(10.6 \%)$, back region in $2(10.6 \%)$, neck in $1(5.2 \%)$, supraclavicular region in $1(5.2 \%)$, axilla in 1 (5.2\%), left hand in $1(5.2 \%)$, sacrum in $1(5.2 \%)$, perineum in $1(5.2 \%)$ and scrotum in $1(5.2 \%)$.

All patients initially presented with complaints of swelling with the exception of 3 cases in which data on the cause of admission was unavailable.

Table I: Clinicopathological findings of cases $(n=50)$.

\begin{tabular}{llc}
\hline Variable & & No. of cases (\%) \\
\hline Gender & Female & $24(48)$ \\
& Male & $26(52)$ \\
\hline Age & $\leq 4$ & $24(48)$ \\
& $4-10$ & $13(26)$ \\
& $\geq 10$ & $13(26)$ \\
\hline Type & Lipoma & $26(52)$ \\
& Fibrolipoma & $3(6)$ \\
& Intramuscular lipoma & $2(4)$ \\
& Spindle cell lipoma & $1(2)$ \\
& Lipoblastoma & $19(38)$ \\
& Atypical lipomatous tumor & $2(4)$ \\
& Pleomorphic liposarcoma & $1(2)$ \\
& Myxoid liposarcoma & $2(4)$ \\
\hline Tumor site & Head and neck & $9(18)$ \\
& Lower extremity & $10(20)$ \\
& Lumbosacral & $7(14)$ \\
& Back & $5(10)$ \\
& Upper extremity & $4(8)$ \\
& Gluteus & $3(6)$ \\
& Inguinal & $2(4)$ \\
& Intradural-extramedullary & $2(4)$ \\
& Others & $8(16)$ \\
\hline
\end{tabular}


The radiological imaging findings were available in 10 cases, revealing a well-circumscribed, slightly heterogeneous and solid mass lesion with an echogenicity similar to adipose tissue (Figure 1A).

Microscopically, there were single and multi-vacuolated adipocytes separated by fibrous septa, stellate-nodular cells and lobules composed of myxoid stroma. No nuclear atypia or mitosis was detected (Figure 1B).

Of the lipoblastoma cases, 10 did not attend follow-up after the diagnosis while 9 had a follow-up period ranging from 3 to 72 months (mean: 26.1 months).

Two of the cases in our series of pediatric lipomatous tumors had atypical lipomatous tumor. One was an 8-yearold female who had a tumor localized in her left thigh with a diameter of $8 \mathrm{~cm}$. The other case was a 10-year-old female who had a retroperitoneal tumor with a diameter of $17 \mathrm{~cm}$. The radiological examination of these cases, who presented with complaints of swelling, revealed a mass lesion with an echogenicity similar to that of surrounding adipose tissue.

Histopathological evaluation revealed hyperchromatic and large nucleus cells; lipoblasts were rarely more common in thin fibrous septa separating the adipocytes and there were differences in size and shape of the adipocytes. The tumor was separated from surrounding tissue with a thin fibrous capsule (Figure 2A). The immunohistochemical analyses performed on the tumor of the first case were positive for MDM2 and CDK4 (Figure 3A,B).

The pleomorphic liposarcoma case was a 15-year-old male with a $3 \mathrm{~cm}$ diameter tumor localized in his back region. We were unable to obtain the radiological findings of this case, who was admitted to the clinic with complaints of swelling.

Histopathological evaluation revealed a tumoral lesion composed of giant and pleomorphic spindle shaped cells with multivacuolar lipoblasts showing prominent pleomorphism. The surgical margins of the lesion were evaluated as intact. The immunohistochemical analyses performed on the tumor with total excision revealed negative staining for MDM2 and CDK4. Lipoblasts were stained positive for $\mathrm{S} 100$.

One of the myxoid liposarcoma cases was a 16-year-old female with a $10 \mathrm{~cm}$ diameter tumor localized in her right thigh. The other case was a 12-year-old female with a tumor of $4 \mathrm{~cm}$ diameter localized in her left popliteal fossa.
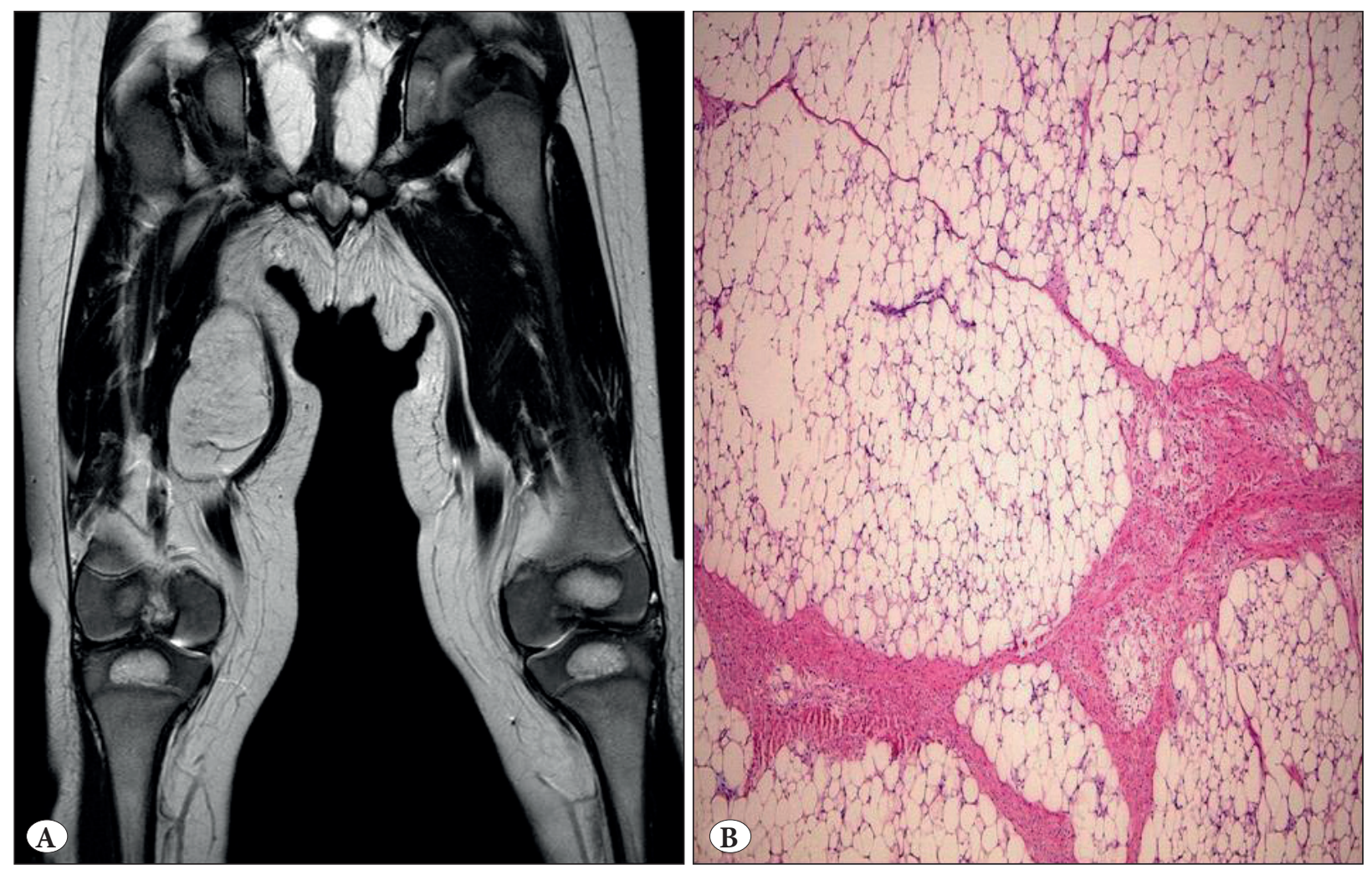

Figure 1: A) Radiographic image of T2A coronal section of lipoblastoma case. B) Lipoblastoma is composed of spindle shaped adipocytes admixed with multi-vacuolated or signet ring lipoblasts in the myxoid stroma (H\&E; x100). 

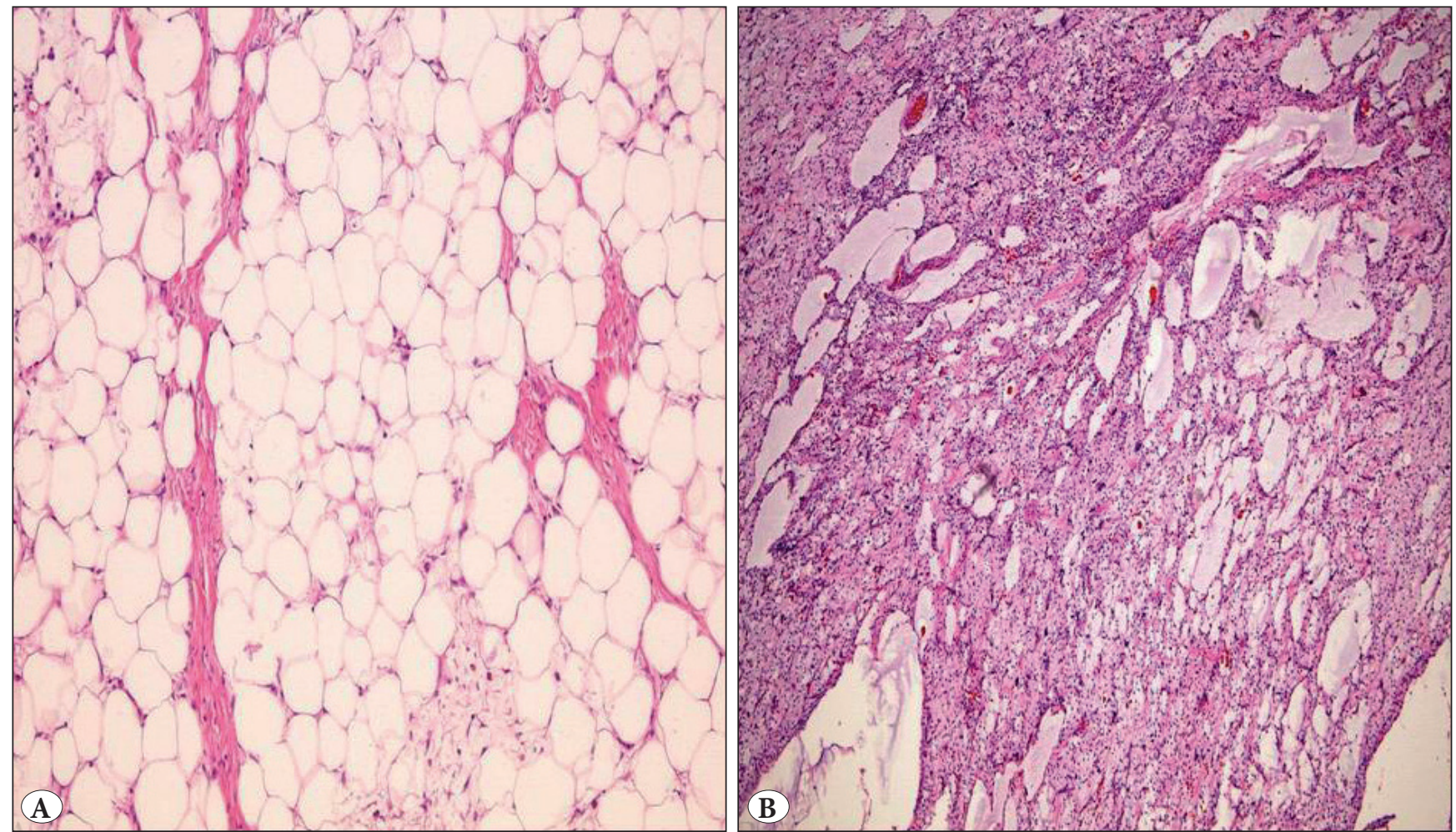

Figure 2: A) Well-differentiated liposarcoma composed of mature fat with variably sized adipocytes and bands of fibrotic stroma containing spindle cells with enlarged, hyperchromatic nuclei (H\&E; x100). B) Myxoid liposarcoma composed of uniform, small spindle and oval cells and thin capillary network in the myxoid stroma (H\&E; x100).
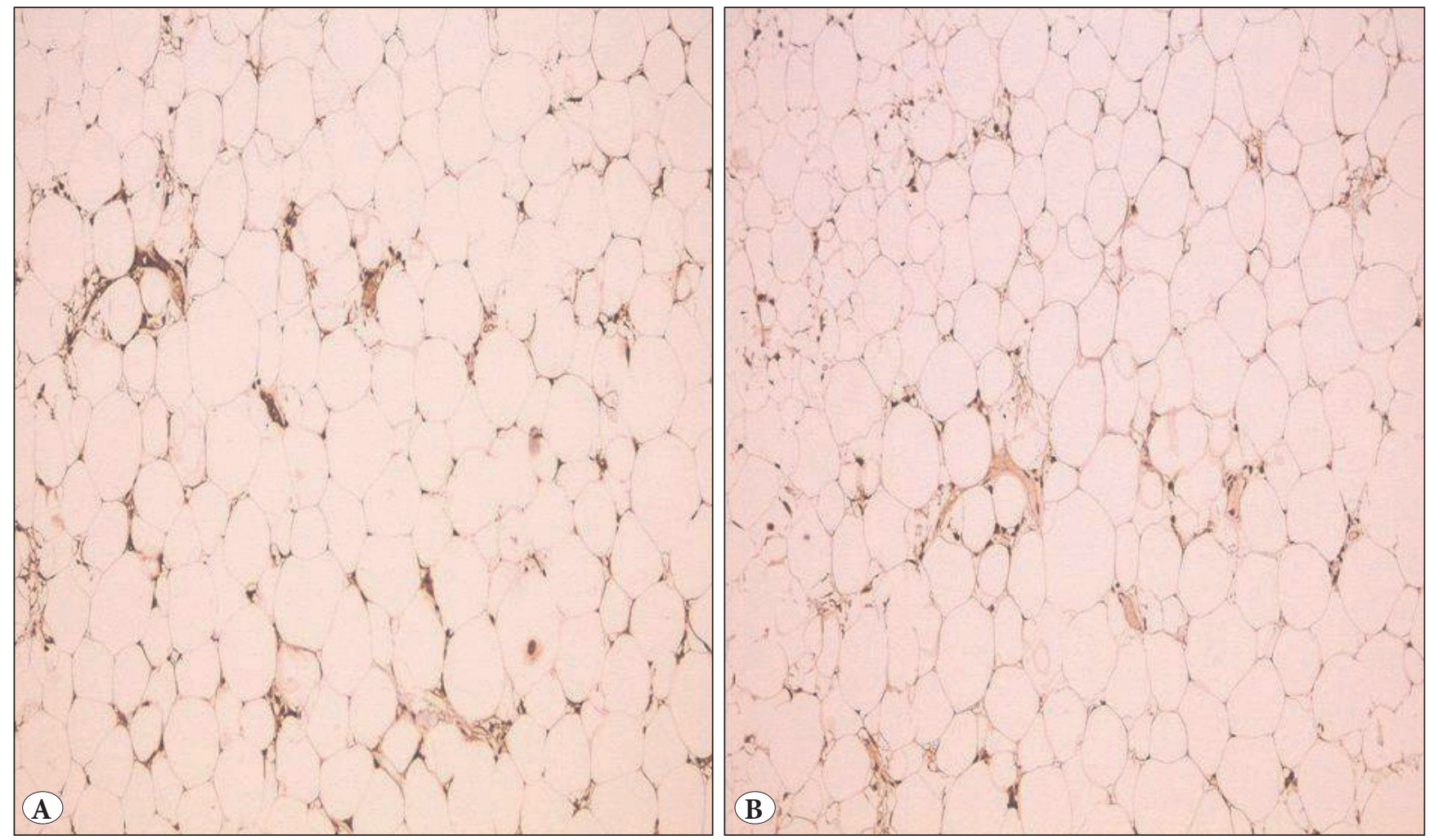

Figure 3: A) MDM2 positivity (IHC; x100). B) CDK4 positivity (IHC; x100). 
We were unable to obtain the radiological findings of these cases, who were both admitted to the clinic with complaints of swelling and underwent total excision.

Histopathological evaluation revealed a tumoral lesion composed of uniform, small spindle and oval cells and thin capillary network in the myxoid stroma. There were extracellular mucin pools in the tumor. A fibrous pseudocapsular structure surrounded the multinodular tumor and the surgical margins were evaluated as intact (Figure 2B). The second myxoid liposarcoma case developed recurrence two years later. All of the liposarcoma cases are still alive and healthy.

\section{DISCUSSION}

Lipomatous tumors comprise approximately $6 \%$ of all softtissue tumors in children (8). Data on the prevalence and incidence of these tumors is insufficient since there is a limited number of studies on pediatric lipomatous tumors in the literature. Benign lipomatous tumors accounted for $8.73 \%$ of the total of 385 cases in the pediatric tumor series of Punia et al. in which 11 of the 24 cases were between 0 and 4 years of age, and the female to male ratio was 0.84 (9). In our study, this ratio was 0.92 .

Lipoma is a benign mesenchymal tumor composed of mature lipocytes. It is especially common in adults aged 40 - 60 years and rarely occurs before 20 years of age $(1,10$, $11)$.

The definite etiology of lipoma has not yet been clarified, although publications suggest that genetic, endocrine, and traumatic factors play a role. Lipoma may also accompany various syndromes such as Gardner's syndrome, Madelung's disease, and Dercum's disease (12).

Lipomas can be subcutaneous or deep-seated. Deep-seated lipomas are divided into two types as intramuscular (situated between muscle fibers) and intermuscular (admixed with muscle fibers). Intramuscular lipomas are typically localized in the chest wall, head-neck region, and lower and upper extremities, while intermuscular lipomas are located in the anterior wall of the abdomen. Retroperitoneal lipomas, however, are very rare. Periosteal lipoma (bone surfaceseated) and lipoma arborescence (synovium-seated) are lipomas specifically named according to their locations $(1,13-15)$. In our series, 2 of the 24 cases had intramuscular and 2 had intradural extramedullary lipomas, with the remaining cases being of the superficial type.

The cases had clinical presentations as mobile, painless, and palpable masses; however, due to their slow-growing nature, lipomas can also be detected incidentally without any symptoms. Larger lipomas may also cause various symptoms by compressing surrounding tissue (16). In our series, the most common cause of admission was complaints of swelling according tuo the data obtained from patient records.

Ultrasonography is the preferred method of radiological imaging for lipomas. The general ultrasonographic appearance is hyperechoic, admixed with the surrounding muscle tissue and parallel to the skin, as an elliptical or rounded mass lesion. MR or CT imaging may be helpful in assessing the lesion and margins appear as fuzzy-bordered or large-sized masses (17). In the 11 cases with accessible radiological imaging in our series, the ultrasonographic findings were in the form of a well-defined mass lesion with an echogenicity of soft tissue.

Although typically smaller than $5 \mathrm{~cm}$, the literature mentions "giant lipomas" larger than $10 \mathrm{~cm}$, weighing over 1000 gr $(2,11)$. Our lipoma cases were macroscopically well-defined, homogeneous mass lesions with yellow cross sections, separated from the surrounding tissue with thin fibrous capsules. The average diameter in our series was $4.84 \pm 3.1 \mathrm{~cm}$.

Microscopically, lipomas appear as well-defined masses composed of mature adipocyte lobules. As an exception, intramuscular lipomas have borders that appear infiltrative. Variants include angiolipoma, spindle cell lipoma, pleomorphic lipoma, chondroid lipoma, myolipoma, myelolipoma, fibrolipoma, and fibrohistiocytic lipoma. Well-differentiated liposarcoma is especially important in the differential diagnosis of intramuscular tumors. The features that distinguish lipoma from liposarcoma include pleomorphism, mitosis, hyperchromatic nucleus, and absence of bizarre cells and lipoblasts $(1,2,18)$. In our series of 24 cases, 3 were fibrolipoma, 2 were intramuscular lipoma, and the remaining cases had typical lipoma morphology.

Molecular genetic examinations of the lipomas revealed ring/giant chromosomes and the rearrangement of the HMGA2 gene $(1,19)$. In the lipoma tumor series by Bartuma et al., 8 of the 272 cases were between 0 and 20 years of age and 3 of these 8 cases had rearrangement of $12 q 13$, one had rearrangement of $6 \mathrm{p} 21$, one had a ring chromosome, and 3 had different karyotypic abnormalities (20).

Lipoblastoma is a benign mesenchymal tumor arising from embryonic white fat tissue. These tumors, which rarely accur in adolescents and adults, account for less than $1 \%$ of all childhood tumors (21). 
Lipoblastomas are more common in males than females, and $90 \%$ of them are diagnosed before 3 years of age $(1,22)$. In our series, the mean age of the cases was $20.3 \pm 29.4$ months with a male predominance as consistent with the literature.

Lipoblastomas can be divided into two groups according to their locations and margins with the surrounding tissue. The term lipoblastoma refers to superficial, encapsulated, and well-defined tumors, whereas the term lipoblastomatosis refers to deep-seated infiltrative tumors (23). All cases in our series were superficial tumors with lipoblastoma morphology.

Lipoblastomas are most commonly located in the trunk and extremities, but may also occur in other regions including the retroperitoneum, pelvis, abdomen, mesentery, mediastinum, head and neck, and solid organs (24). In their series of 32 cases, Speer et al. reported that 12 of the cases were located in the trunk, 12 were in the extremities, 5 were in the inguinal region and 3 were in the neck (25). In our series, the locations of tumors included the extremities in 7 , the gluteal area in 2, the inguinal region in 2, the back region in 2, the supraclavicular area in 1, the axillary area in 1 , the sacrum in 1 , the perineum in 1 , and the scrotum in 1 .

Similar to lipomas, if any symptoms occurred, the clinical presentations of the cases were with complaints of mobile, painless and palpable masses. When they attain large sizes, pressure on the surrounding tissues may cause various symptoms (26). According to the data obtained from archive reports, the most common complaint at presentation was swelling in our series.

Although radiological imaging is considered useful in diagnosing lipoblastoma, a radiological finding by itself does not rule out malignancy. MRI is more preferred in lipoblastomas than CT, with higher signal intensity and heterogeneity in T1-weighted images, and moderate in T2-weighted images $(27,28)$. The 10 cases with available ultrasonography reports in our series, showed a welldefined, mildly heterogeneous, solid mass lesion with an echogenicity similar to adipose tissue.

These tumors were macroscopically well-defined, lobulated, soft mass lesions with yellow-white cross sections. There were also myxoid areas in some tumors. They were typically $2-5 \mathrm{~cm}$ in size, but they can also be larger $(1,2)$. In our series, the mean tumor diameter was $4.87 \pm 2.4 \mathrm{~cm}$ (range: $0,3-9 \mathrm{~cm}$ ).

Microscopically, there were single and multi-vacuolated adipocytes separated by fibrous septa, stellate-nodular cells and lobules composed of myxoid stroma. The findings of nuclear atypia and mitosis were not anticipated (29). Microscopic findings were consistent with the literature in our series.

Molecular genetic examinations of lipoblastomas revealed rearrangements of $8 \mathrm{q} 11 \sim \mathrm{q} 13$, hyaluronic acid synthase 2 (HAS2) and collagen 1 alpha 2 (COL1A2) as well as pleomorphic adenoma gene 1 (PLAG1) amplification (30).

Liposarcomas are malignant tumors with differentiated adipose tissue. These tumors are common in adults; however, they account for less than $3 \%$ of pediatric softtissue sarcomas (31). There are publications reporting a mild female predominance in these tumors which are more common particularly in the second decade in pediatric patients. Ferrari et al. reported the average age of diagnosis as 7 years in their series of 12 cases. The female to male ratio of the cases was 0.5 (32). In our series, the average age of diagnosis as 12.2 in 5 liposarcoma cases (range: 8-16).

Although liposarcomas are mostly localized in the extremities, they can also occur in pelvis, inguinal region, head and neck, chest cavity, axilla, mediastinum, visceral space such as abdominal cavity, and retroperitoneum. Well-differentiated and pleomorphic types of liposarcoma are mostly located in the retroperitoneum and visceral cavity. Studies have shown that tumor localization is associated with histological subtype (33). In their pediatric liposarcoma series of 17 cases, Shmookler et al. reported that the tumors were mostly localized in the lower extremity in 5 cases (34). Of the 5 liposarcoma cases in our series, diagnosed as well-differentiated liposarcomas, localization was in the lower extremity and retroperitoneum; the myxoid liposarcomas were localized in the lower extremity while the single case of pleomorphic liposarcoma was localized in the back region.

The most common type of liposarcoma in the pediatric age group is myxoid/round-cell liposarcoma, which consists of well-differentiated, de-differentiated, myxoid/roundcell and pleomorphic subtypes. Approximately 5\% of liposarcomas do not carry the characteristics of a particular subtype, and are therefore called "mixed type liposarcoma". Liposarcomas in adults have macroscopic and microscopic features that are similar to those in the pediatric age group. They are generally large-sized $(>5 \mathrm{~cm})$, multinodular, pale yellow or bronze colored masses. They may include regions of hemorrhage and necrosis as well as myxoid-gelatinous or non-lipogenic areas depending on the type of liposarcoma. Unlike benign lipomatous tumors, liposarcomas may have infiltrative borders, and are composed of lipoblasts, thick 
fibrous septa, hyperchromatic atypical cells and atypical mitosis $(1,2,31,35)$. In their series of 82 cases under 22 years of age, Allagio et al. found that 58 cases $(71 \%)$ were diagnosed with myxoid and round-cell liposarcoma, 12 cases (15\%) with pleomorphic myxoid liposarcoma, 6 cases (7\%) with spindle cell myxoid liposarcoma, 4 cases (5\%) with well-differentiated liposarcoma, and 2 cases (2\%) with pleomorphic liposarcoma (36). In our series, 2 cases (4\%) were diagnosed with atypical lipomatous tumor, 2 cases (4\%) with myxoid liposarcoma and 1 case (2\%) with pleomorphic liposarcoma.

Molecular and cytogenetic examination of liposarcomas revealed ring chromosomes and long determinant chromosomes originated from the 12q13-15 region, amplifications of MDM2, CDK4 and HMGA2 in welldifferentiated and dedifferentiated liposarcomas as well as translocations of $(12 ; 16)(\mathrm{q} 13 ; 11)$ and $(12 ; 22)(\mathrm{q} 13 ; \mathrm{q} 22)$ caused by rearrangements of FUS-CHOP or EWSR1$\mathrm{CHOP}$ in myxoid liposarcomas. There were complex karyotypic abnormalities in pleomorphic liposarcomas but no specific cytogenetic abnormality was found (37).

In addition to assessment of morphological features, immunohistological staining is an adjuvant method in distinguishing between malignant and benign lipomatous tumors. MDM2 and CDK4 nuclear staining is not a characteristic of benign lipomatous tumors in welldifferentiated and dedifferentiated liposarcomas; however, it should be noted that it is not encountered in myxoid and round cell pleomorphic liposarcomas $(2,38)$. In our series, the immunohistochemical analyses performed on the first case of atypical lipomatous tumor stained positive for MDM2 and CDK4.

In the differential diagnosis of liposarcoma, Ewing/PNET group sarcomas, rhabdomyosarcoma, neuroblastoma, extraskeletal mesenchymal chondrosarcoma have an important place as the myxoid-round cell liposarcoma is the most common subtype in pediatric age group (2). Immunohistochemical and molecular findings as well as histomorphological findings are also useful. Detailed information on benign and malignant entities in the differential diagnosis is presented in Table II.

Treatment of benign and malignant lipomatous tumors involves a total excision with safe margins. Welldifferentiated and low-grade tumors generally have better prognosis and do not develop any distant metastasis. These tumors should be investigated for the possibility of local recurrence.

Studies report that total excision and radiotherapy should be performed together to prevent local recurrence. Poorly differentiated and high-grade tumors have poor prognosis and may establish distant metastases. In addition to liposarcomas, $10-20 \%$ of recurrence can be detected in lipoblastomatosis, particularly in lipoblastomas $(2,35,39,40)$. We found no recurrence in the 9 lipoblastoma cases in the follow-up of our series. We found recurrence in one of the myxoid liposarcoma cases after two years. However, the other cases of liposarcoma could not be evaluated in terms of recurrence or metastasis.

Table II: Major entities in differential diagnosis of liposarcomas.

\begin{tabular}{llll}
\hline Benign entities & Clinical features & Microscopic features & Assistive techniques \\
\hline Fat necrosis & $\begin{array}{l}\text { There is no specific } \\
\text { feature. } \\
\begin{array}{l}\text { The history of trauma } \\
\text { is significant in the } \\
\text { anamnesis. }\end{array}\end{array}$ & $\begin{array}{l}\text { Necrotic lipomatous tissue, } \\
\text { foamy macrophages } \\
\text { Lipoblast-like cells may be } \\
\text { seen }\end{array}$ & $\begin{array}{l}\text { While MDM2 and CDK4 are } \\
\text { generally negative, macrophages } \\
\text { show positive staining with CD68. }\end{array}$ \\
\hline $\begin{array}{l}\text { Lipoma containing fat } \\
\text { necrosis }\end{array}$ & $\begin{array}{l}\text { Generally good limited, } \\
\text { superficial masses. The } \\
\text { anamnesis may include } \\
\text { a history of trauma. }\end{array}$ & $\begin{array}{l}\text { Mature adipocytes and fat } \\
\text { necrosis findings without } \\
\text { hyperchromatic-large cells }\end{array}$ & $\begin{array}{l}\text { While MDM2 and CDK4 are } \\
\text { generally negative, macrophages } \\
\text { show positive staining with CD68. }\end{array}$ \\
\hline $\begin{array}{l}\text { Silicone granuloma } \\
\text { They develop due to the }\end{array}$ & $\begin{array}{l}\text { A number of lipoblast-like } \\
\text { cells and inflammatory } \\
\text { rupture of the implant } \\
\text { in patients with a } \\
\text { history of mammary } \\
\text { implant. }\end{array}$ & $\begin{array}{l}\text { While MDM2 and CDK4 are } \\
\text { the lobules and the ductus. }\end{array}$ & $\begin{array}{l}\text { generally negative, macrophages } \\
\text { show positive staining with CD68. }\end{array}$ \\
& & & \\
\hline
\end{tabular}


Table II continue

\begin{tabular}{|c|c|c|c|}
\hline Spindle cell lipomas & $\begin{array}{l}\text { Superficial masses } \\
\text { typically located at the } \\
\text { shoulder and back. }\end{array}$ & $\begin{array}{l}\text { Lipomatous areas with non- } \\
\text { atypical collagenized spindle } \\
\text { cells are observed. }\end{array}$ & $\begin{array}{l}\text { While MDM2 and CDK4 are } \\
\text { generally negative, CD } 34 \text { is positive. } \\
\text { Unbalanced karyotypes / } \\
\text { hypodiploidy, partial losses and } \\
\text { monosomy } 13 \text { are detected. }\end{array}$ \\
\hline Pleomorphic lipomas & $\begin{array}{l}\text { They are superficial } \\
\text { masses typically located } \\
\text { at the shoulder and } \\
\text { back. }\end{array}$ & $\begin{array}{l}\text { Lipomatous areas with } \\
\text { non-atypical collagenized } \\
\text { spindle cells and floret-like } \\
\text { hyperchromatic giant cells. }\end{array}$ & $\begin{array}{l}\text { While MDM2 and CDK4 are } \\
\text { generally negative, CD } 34 \text { is positive. } \\
\text { Unbalanced karyotypes / } \\
\text { hypodiploidy, partial losses and } \\
\text { monosomy } 13 \text { are detected. }\end{array}$ \\
\hline Hibernomas & $\begin{array}{l}\text { Generally located at the } \\
\text { thigh at an early age. }\end{array}$ & $\begin{array}{l}\text { A lobulated lesion lacking } \\
\text { hyperchromasia which } \\
\text { consists of intracytoplasmic } \\
\text { vacuolar adipocytes. }\end{array}$ & $\begin{array}{l}\text { Chromosome 11q13 abnormalities } \\
\text { are detected. }\end{array}$ \\
\hline Myxomas & $\begin{array}{l}\text { Generally located at } \\
\text { the thigh, shoulder and } \\
\text { upper arm in adults. }\end{array}$ & $\begin{array}{l}\text { Hypocellular lesions with } \\
\text { poor vascular structures. }\end{array}$ & $\begin{array}{l}\text { While spindle cells are positive with } \\
\text { CD34 and Vimentin staining, they } \\
\text { are generally negative with S100 and } \\
\text { Desmin staining. } \\
\text { GNAS mutation is present. }\end{array}$ \\
\hline \multicolumn{4}{|l|}{ Malignant Entities } \\
\hline $\begin{array}{l}\text { Undifferentiated } \\
\text { pleomorphic sarcoma }\end{array}$ & $\begin{array}{l}\text { Usually detected in } \\
\text { adult patients as deeply } \\
\text { localized. }\end{array}$ & $\begin{array}{l}\text { They are tumors consisting } \\
\text { of pleomorphic spindle cells } \\
\text { with storiform pattern. }\end{array}$ & $\begin{array}{l}\text { While MDM2 and CDK4 are } \\
\text { generally negative, variable SMA and } \\
\text { Desmin positivity may be detected. }\end{array}$ \\
\hline $\begin{array}{l}\text { Ewing/PNET group } \\
\text { sarcomas }\end{array}$ & Generally young. & $\begin{array}{l}\text { They are tumoral lesions } \\
\text { with round or oval shape } \\
\text { with vesicular nucleus, fine } \\
\text { chromatin, narrow cytoplasm } \\
\text { and uniform appearance. }\end{array}$ & $\begin{array}{l}\text { While CD } 99 \text { and FLI-1 are positive, } \\
\text { neuroendocrine markers can detect } \\
\text { positivity, too. } \\
\text { EWSR1 translocation is detected. }\end{array}$ \\
\hline Rhabdomyosarcomas & Generally young. & $\begin{array}{l}\text { They are spindle cell tumors } \\
\text { with no lipoblasts, containing } \\
\text { cells with significant } \\
\text { eosinophilic cytoplasm. }\end{array}$ & $\begin{array}{l}\text { Desmin, MyoD1 and Myogenin are } \\
\text { detected positive. } \\
\text { FOXO1 translocation is observed in } \\
\text { alveolar type rhabdomyosarcoma. }\end{array}$ \\
\hline Neuroblastomas & $\begin{array}{l}\text { Generally under } 2 \text { years } \\
\text { of age. }\end{array}$ & $\begin{array}{l}\text { They are tumors consisting } \\
\text { of round or oval shaped cells } \\
\text { with minimally amphophilic } \\
\text { cytoplasm and varying } \\
\text { proportions of neurofibrillary } \\
\text { matrix. }\end{array}$ & $\begin{array}{l}\text { Positive staining is detected by } \\
\text { neuroendocrine markers. nMYC } \\
\text { amplification can be seen. }\end{array}$ \\
\hline Myxofibrosarcomas & $\begin{array}{l}\text { Superficial masses } \\
\text { spreading throughout } \\
\text { the fascia in patients } \\
\text { with advanced age. }\end{array}$ & $\begin{array}{l}\text { They are myxoid tumors rich } \\
\text { in pleomorphic spindle cells } \\
\text { and thick walled vessels. }\end{array}$ & $\begin{array}{l}\text { Generally CD34 and SMA positivity } \\
\text { are detected. However, there is no } \\
\text { specific immunuhistochemical } \\
\text { staining. }\end{array}$ \\
\hline $\begin{array}{l}\text { Other sarcomas } \\
\text { infiltrating the } \\
\text { surrounding fat tissue }\end{array}$ & & $\begin{array}{l}\text { Atypia, shape-size differences } \\
\text { are only detected in } \\
\text { adipocytes located in the } \\
\text { surrounding fat tissue. }\end{array}$ & MDM2 and CDK4 are negative. \\
\hline
\end{tabular}


In conclusion, lipomatous tumors are the most common type of mesenchymal tumors in adults, but rarely occur in children. Tumors localized in deep tissues may especially slowly enlarge to greater sizes and cause various clinical symptoms by compressing surrounding tissues. Local recurrences, which may develop even after total excision, necessitate close monitoring of the cases.

\section{CONFLICT of INTEREST}

The authors declare no conflict of interest.

\section{REFERENCES}

1. Fletcher CDM, Bridge JA, Hogendoorn P, Mertens F. World Health Organization Classification of Tumours of Soft Tissue and Bone: Adipocytic tumors. 4th ed. Lyon: IARC Press; 2013. 20-43.

2. Fisher C, Montgomery EA, Thway K. Biopsy interpretation series biopsy interpretation of the soft tissue tumors. 2th ed. Philadelphia: Lippincott Williams and Wilkins; 2011. 355-402.

3. Lindberg MR, Lucas D, Cassorino DS, Gardner JM, StallingsArcher K. Diagnostic pathology soft tissue tumors. 2th ed. Philadelphia: Elsevier - Health Sciences Division; 2016. 44-98.

4. Kamra HT, Munde SL. Lipoma on palmar aspect of thumb: A rare case report. J Clin Diagn Res. 2013; 7:1706-7.

5. McTighe S, Chernev I. Intramuscular lipoma: A review of the literature. Orthop Rev (Pavia). 2014; 6:5618.

6. Sciot R, De Wever I, Debiec-Rychter M. Lipoblastoma in a 23-year-old male: Distinction from atypical lipomatous tumor using cytogenetic and fluorescence in-situ hybridization analysis. Virchows Arch. 2003; 442:468-71.

7. Huh WW, Yuen C, Munsell M, Hayes-Jordan A, Lazar AJ, Patel S, Wang WL, Barahmani N, Okcu MF, Hicks J, Debelenko L, Spunt SL. Liposarcoma in children and young adults: A multiinstitutional experience. Pediatr Blood Cancer. 2011; 57:1142-6.

8. Kim HJ, Yang I, Jung AY, Hwang JH, Shin MK. Angiomyxolipoma (vascular myxolipoma) of the knee in a 9-year-old boy. Pediatr Radiol. 2010; 40:S30-3.

9. Punia RS, Mundi I, Kundu R, Jindal G, Dalal U, Mohan H. Spectrum of nonhematological pediatric tumors: A clinicopathologic study of 385 cases. Indian J Med Paediatr Oncol. 2014; 35:170-4.

10. Murphey MD, Carroll JF, Flemming DJ, Pope TL, Gannon FH, Kransdorf MJ. From the archives of the AFIP: Benign musculoskeletal lipomatous lesions. Radiographics. 2004; 24:1433-66.

11. Çıraklı A, Dabak N, Çıraklı S, Sezgin H, Göçer H, Barış S. Distribution of pediatric bone and soft tissue tumors in the central Black Sea region. Turk J Pediatr. 2014; 56:226-31.

12. Eryılmaz MA, Yücel A, Yücel H, Arıcıgil M. Cervico-thoracic giant lipoma in a child. Turk Arch Otorhinolaryngol. 2016; 54:82-5.

13. Myint ZW, Chow RD, Wang L, Chou PM. Ossifying parosteal lipoma of the thoracic spine: A case report and review of literature. J Community Hosp Intern Med Perspect. 2015; 5:26013.
14. McTighe S, Chernev I. Intramuscular lipoma: A review of the literature. Orthop Rev (Pavia). 2014; 6:5618.

15. Cil A, Atay OA, Aydingöz U, Tetik O, Gedikoğlu G, Doral MN. Bilateral lipoma arborescens of the knee in a child: A case report. Knee Surg Sports Traumatol Arthrosc. 2005; 13:463-7.

16. Sharma BK, Khanna SK, Bharati M, Gupta A. Anterior neck lipoma with anterior mediastinal extension - A rare case report. Kathmandu Univ Med J. 2013; 11:88-90.

17. Kim KS, Yang HS. Unusual locations of lipoma: Differential diagnosis of head and neck mass. Aust Fam Physician. 2014; 43:867-70.

18. Lee JH, Do HD, Lee JC. Well-circumscribed type of intramuscular lipoma in the chest wall. J Cardiothorac Surg. 2013; 8:181.

19. Macarenco RS, Erickson-Johnson M, Wang X, Folpe AA Rubin BP, Nascimento AG, Oliveira AM. Retroperitoneal lipomatous tumors without cytologic atypia: Are they lipomas? A clinicopathologic and molecular study of 19 cases. Am J Surg Pathol. 2009; 33:1470-6.

20. Bartuma H, Hallor KH, Panagopoulos I, Collin A, Rydholm A, Gustafson P, Bauer HC, Brosjö O, Domanski HA, Mandahl N, Mertens F. Assessment of the clinical and molecular impact of different cytogenetic subgroups in a series of 272 lipomas with abnormal karyotype. Genes Chromosomes Cancer. 2007; 46:594606.

21. Nagano Y, Uchida K, Inoue M, Ide S, Shimura T, Hashimoto K, Koike Y, Kusunoki M. Mesenteric lipoblastoma presenting as a small intestinal volvulus in an infant: A case report and literature review. Asian J Surg. 2017;40:70-3.

22. Kerkeni Y, Sahnoun L, Ksia A, Hidouri S, Chahed J, Krichen I, Mekki M, Belghith M, Nouri A. Lipoblastoma in childhood: about 10 cases. Afr J Paediatr Surg. 2014; 11:32-4.

23. Miller GG, Yanchar NL, Magee JF, Blair GK. Lipoblastoma and liposarcoma in children: An analysis of 9 cases and a review of the literature. Can J Surg. 1998; 41:455-8.

24. Chun YS, Kim WK, Park KW, Lee SC, Jung SE. Lipoblastoma. J Pediatr Surg. 2001; 36:905-7.

25. Speer AL, Schofield DE, Wang KS, Shin CE, Stein JE, Shaul DB, Mahour GH, Ford HR. Contemporary management of lipoblastoma. J Pediatr Surg. 2008; 43:1295-300.

26. Susam-Sen H, Yalcin B, Kutluk T, Cahit Tanyel F, Haliloglu M, Orhan D, Aydin B, Kurucu N, Varan A, Akyuz C. Lipoblastoma in children: Review of 12 cases. Pediatr Int. 2017; 59:545-50.

27. Moaath A, Raed E, Mohammed R, Mohammed S. Lipoblastoma A rare mediastinal tumor. Ann Thorac Srg 2009; 88:1695-7.

28. Homma T, Doki Y, Senda K, Toge M, Yamamoto Y, Ojima T, Shimada Y, Yoshimura N. Rare lipomatous tumor of the posterior mediastinum in children. European J Pediatr Surg Rep. 2014; 2:50-3.

29. Pham NS, Poirier B, Fuller SC, Dublin AB, Tollefson TT. Pediatric lipoblastoma in the head and neck: A systematic review of 48 reported cases. Int J Pediatr Otorhinolaryngol. 2010; 74:723-8.

30. Morerio C, Rapella A, Rosanda C, Tassano E, Gambini C, Romagnoli G, Panarello C. PLAG1-HAS2 fusion in lipoblastoma with masked 8q intrachromosomal rearrangement. Cancer Genet Cytogenet. 2005; 156:183-4. 
31. Coffin CM, Alaggio R. Adipose and myxoid tumors of childhood and adolescence. Pediatr Dev Pathol. 2012; 15:239-54.

32. Ferrari A, Casanova M, Spreafico F. Childhood liposarcoma: A single-institutional twenty-year experience. Pediatr Hematol Oncol. 1999; 16:415-21.

33. Huh WW, Yuen C, Munsell M, Hayes-Jordan A, Lazar AJ, Patel S, Wang WL, Barahmani N, Okcu MF, Hicks J, Debelenko L, Spunt SL. Liposarcoma in children and young adults: A multiinstitutional experience. Pediatr Blood Cancer. 2011; 57:1142-6.

34. Shmookler BM, Enzinger FM. Liposarcoma occurring in children. An analysis of 17 cases and review of the literature. Cancer. 1983; 52:567-74.

35. Anand Rajan KD, Subbarao KC, Agarwala S, Gupta SD. Mediastinal liposarcoma of mixed type in childhood: A report of a case with unusual histologic features. Indian J Pathol Microbiol. 2010; 53:525-8.
36. Alaggio R, Coffin CM, Weiss SW. Liposarcomas in young patients: A study of 82 cases occurring in patients younger than 22 years of age. Am J Surg Pathol 2009; 33:645-58.

37. Dei Tos AP. Liposarcomas: Diagnostic pitfalls and new insights. Histopathology. 2014; 64:38-52.

38. Ortega P, Suster D, Falconieri G, Zambrano E, Moran CA, Morrison C, Suster S. Liposarcomas of the posterior mediastinum: Clinicopathologic study of 18 cases. Mod Pathol. 2015; 28:72131.

39. Stein-Wexler R. Pediatric soft tissue sarcomas. Semin Ultrasound CT MR. 2011; 32:470-88.

40. Arici A, Ozgur T, Ugras N, Yalcinkaya U. Immunohistochemical detection of p53 and MDM2 expressions in liposarcoma with World Health Organization Classification. Indian J Cancer. 2013; 50:164-9. 